\title{
TUDÁSORIENTÁLT SZERVEZETEK ÉRTÉKÍTÉLETE A BIZALOM GAZDASÁGI HATÁSAIRÓL
}

A szerzők dolgozatukban speciális nézőpontból vizsgálják a szervezeti bizalmat, mivel feltételezéseik szerint a bizalomnak a tudásátadásban és megosztásban kritikus versenyképességi tényezőként kiemelkedő jelentősége van.

A szerzők a vizsgálatokat nemzetközi összehasonlításban végezték, és széles körű hipotézisrendszert állítottak fel, melynek egy részét mutatja be a tanulmány.

A kutatási kérdéseik megválaszolása érdekében először elméleti áttekintést adnak a nemzetközi szakirodalomban található, kapcsolódó kutatások eredményeiről, majd bemutatják a vizsgálati modellt, mely hipotéziseik összefüggéseit ábrázolja. Végül a kérdőíves felmérés eredményeit tárják az olvasók elé.

\section{Kulcsszavak: bizalom, tudásmenedzsment-rendszer, vállalati stratégia}

É vtizedek kutatásai rávilágítottak a bizalom központi szerepére a sikeres szervezeti müködésben (Ellonen et al., 2008; Gilbert - Tang, 1998; Wech, 2002). A munkahelyi bizalom vizsgálatának kezdete a múlt század hatvanas éveinek elejére tehető, mely egyre népszerübbé vált a tudományos kutatásokban (Tan - Lim, 2009; Paliszkiewicz et al., 2014).

A nemzetközi kutatások a bizalom és/vagy bizalmatlanság szervezeti következményei hatásának vizsgálata során elsősorban elméleti szinten kerültek górcső alá, összefüggésben a kommunikáció, etika, elkötelezettség, kultúra és/vagy egyéb vállalati sikertényezőkkel (Rahman et al., 2015; Azman et al., 2013; Ayoko - Pekerti, 2016). A kutatások mindegyike bizonyította, hogy a bizalmi légkör, a bizalomra épülő szervezeti kultúra erősíti a munkatársak közötti összetartást, segíti a tudásmegosztás sikerességét, az egymásra figyelést, hatékonyabb munkát és őszinte kommunikációt eredményez. A kézzelfogható, számszerüsíthető eredmények szintjén ritkán találkozunk tudományos vizsgálatok eredményeivel, vagyis nem számítják ki a bizalom és/vagy bizalmatlanság, illetve a túlzott bizalom gazdasági hatását a szervezeti működésre.

Jelen tanulmány ily módon egyfajta hiány pótlása a fenti témakörben. Speciális nézőpontból vizsgáljuk a szervezeti bizalmat, mivel feltételezéseink szerint a bizalomnak a tudásátadásban és megosztásban kritikus versenyképességi tényezőként kiemelkedő jelentősége van. Leginkább érezhető a pozitív és/vagy negatív gazdasági következmény a tudásmenedzsment (TM) stratégiát preferáló és/vagy tudásmenedzsmentrendszer-építést (TMR) kezdeményező szervezetek esetében. Ezért a bizalom és/ vagy bizalmatlanság következményeit olyan szervezetek példáján érdemes vizsgálni, melyek elsősorban a tudástőke jelentőségét hangsúlyozzák saját tevékenységük kapcsán. Ezeket a szervezeteket nevezhetjük tudásalapú/tudásorientált/tudástökére épülö/tudásintenzív szervezeteknek. A későbbiekben az elnevezéseket mind az elméleti, mind a gyakorlati kutatásokban szinonimaként használjuk. A tudásorientált szervezetek keretein belül működő tudásmenedzsment-modell építőköveinek végigkísérése során tapasztalható bizalom és/vagy annak hiánya kapcsán felismerhető problémák, azok következményei, ellentmondások feltárása és hatásaik elemzése a kutatás fó célja.

A következő kutatási kérdések fogalmazódtak meg: Megtalálhatók-e a szervezetekben a tudásmenedzsment-rendszerek müködésére utaló elemek, módszerek? Ha igen, támogatja-e a bizalomra épülő szervezeti kultúra e módszerek sikeres alkalmazását? Foglalkoznak-e és ha igen, milyen mértékben a szervezetek a munkahelyi környezetben, munkavégzés során megnyilvánuló, tudásmenedzsment-rendszer müködés igényelte bizalom vagy bizalmatlanság bármilyen következményével? Ha foglalkoznak vele, eljutnak-e odáig a vezetők, hogy számszerüen is kalkuláljanak a bizalom okozta pozitív, illetve bizalmatlanság okozta negatív gazdasági következményekkel?

A vizsgálatokat nemzetközi összehasonlításban végeztük, és széles körü hipotézisrendszert állítottunk fel, melynek egy részét mutatja be a tanulmány.

A kutatási kérdéseink megválaszolása érdekében elöször elméleti áttekintést adunk a nemzetközi szakirodalomban található, kapcsolódó kutatások eredményeiről, majd bemutatjuk a vizsgálati modellt, mely a hipotéziseink összefüggéseit ábrázolja. Végül a kérdöíves felmérés eredményeit tárjuk az olvasók elé.

\section{Elméleti alapok}

\section{A tudásmenedzsment és rendszere}

„A tudásmenedzsment olyan üzleti modell, amely a tudást mint a szervezet vagyonát használja fel versenyelőny eléréséhez. Olyan menedzsmenteszköz, amely a szervezet szellemi tőkéjének azonosítását, értékelését, hasznosítását, létrehozását, növelését, védelmét, megosztását és alkalmazását hivatott integrált megközelítésben támogatni” (Davenport - Prusak, 2001, p. 28.).

Prusak (1999), az IBM tudásmenedzsere szerint valójában magát a tudást nem menedzselhetjük. Viszont létrehozhatunk és fenntarthatunk egy olyan környezetet, mely képes a szervezetben rejlő tudást termelőerővé alakítani. Ahhoz, hogy egy ilyen rendszer sikeresen mü- 
ködjön, három egymáshoz kapcsolódó dolog szükséges: a technológia, a folyamatok és az emberek. Ezen elemek együttmüködésének beindításához és mozgásban tartásához elengedhetetlen a tudásmegosztást támogató szervezeti kultúra és a felső vezetés folyamatos, hosszú távú támogatása. Valójában ez hozza müködésbe egy szervezet tudásmenedzsment-rendszerét.

A tudásmenedzsment-rendszerek kiépítésének igénye, illetve a tudásmenedzsment logikájának szervezeti müködésbe integrálása a nyugati társadalmakban évtizedes múltra tekint vissza, míg a kevésbé sikeres gazdaságokban, így Kelet-Közép-Európában kevésbé preferált üzleti modell (Paliszkiewicz - Koohang, 2013).

A rendszerépítés igénye a vezetés, a stratégia szintjén gyakran megfogalmazódik, de az operatív megvalósítás szintjére nagyon kevés cég jut el (Bencsik, 2013). A hazai és a környező országokbeli vizsgálatok eredményei azt igazolják, hogy elsősorban a tudásorientált szervezetek kerülnek leginkább közel az igénystratégiában történő megfogalmazásához. Elszigetelt eszközhasználat vagy módszerbeli megoldások gyakrabban felismerhetők a szervezeti müködésben, de integrált működési modell szintjén nem jellemző a jelenlétük. Ezek a tények indíttatták első hipotézisünket:

\section{Hipotézis 1/a \\ A tudásalapú szervezetek esetében a tudásme- nedzsmentrendszer-épités és müködés igénye meg- fogalmazódik a stratégiában.}

\section{Hipotézis $1 / b$ \\ A stratégiai szinten megfogalmazódó tudásme- nedzsmentrendszer-épités igénye magával hozza a rendszerépités elemeinek megjelenését (Probst-mo- dell elemei) az operativ müködés szintjén is.}

\section{A tudásmenedzsment-folyamat modellje}

A fenti definíció gyakorlatban is hasznosítható folyamatát támasztja alá az egyik legismertebb modell, mely Probst nevéhez füződik. A logika nyolc lépésben járja végig a szervezeti feltételek közötti működtetés állomásait (Probst, 1998). A logika az 1. ábrán látható.

A Probst-modell (Probst, 1998, p. 19.)

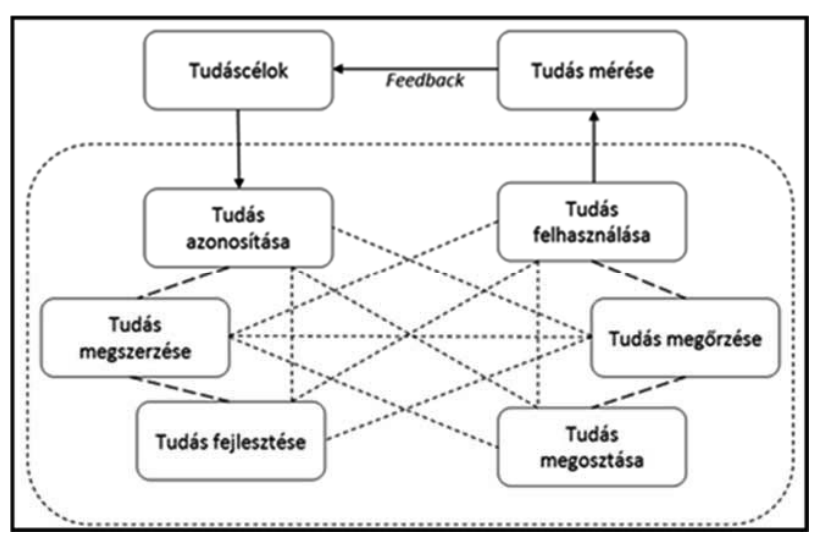

A modell építőköveinek jelentőségét nem tárgyalja a tanulmány, (szakma körökben ismertnek tételezzük fel), de megjegyezzük, hogy valamennyi lépés során a bizalom komoly jelentőséggel bíró befolyásoló tényező. A tanulmány fókuszál a leginkább kritikus lépésre, mely megalapozza a további logikai kapcsolatokat. Ugyanis komoly kihívást jelent a vezetők számára a fenti modell lépései közül a szervezeti tudásmegosztás gyakorlatának kialakítása. A szervezetek versenyképessége, olykor a túlélése is a megosztott tudásban rejlik. Ha ez a tudás nem képes megfelelően áramolni a szervezetben, és az emberek magukban őrzik, nem osztják meg másokkal, akkor nem születhetnek új megoldások, ötletek és az innováció megtorpan. A vezetésnek el kell érnie, hogy a munkavállalók képesek és hajlandóak legyenek tudásukat a többi munkatárssal megosztani. Ehhez a vállalati kultúrát át kell alakítani, és meg kell teremteni a bizalmi légkört, amelyben a dolgozók tudják, nem éri őket hátrány, ha megosztják egymással tudásukat és az a további közös célokat szolgálja.

Korábbi kutatások is igazolják (Kuburic - Kuburic, 2010; Lopez-Fresno - Savolainen, 2014) a bizalom és a tudásmegosztás közötti szoros összefüggést. A kutatási eredmények kellő súllyal történő értékeléséhez a továbbiakban részletesebben áttekintjük a bizalom jelentését, a munkahelyi közösségekben betöltött szerepét, a vállalati sikerhez való hozzájárulását.

\section{A bizalom}

A nemzetközi szakirodalmakban a bizalmat úgy definiálják, mint a sikeres és hatékony szervezeti együttműködés eszközét (Zand, 1997; McAllister, 1995; Lane, 1998; Rousseau et al., 1998; Nooteboom, 2002). Segít a kapcsolatok kialakításában, megkönnyíti az üzleti tárgyalásokat (Olekalns - Smith, 2005), a vállalatok közti cserében csökkenti a tranzakciós költségeket (Bharadwaj - Matsuno, 2006), és megoldja a nemzetközi politikai konfliktusokat (Kelman, 2005).

A bizalom definíciójára számos megfogalmazás olvasható a szakirodalomban, de egységesen és nemzetközi szinten is elfogadott, ma még nem létezik. A tanulmánynak nem célja ezek mérlegre tétele vagy minősítése, különösen nem szociológiai és/vagy pszichológiai értelemben. A hazai feltételekre és nemzeti kultúrára tekintettel választva - a tanulmány menedzsmentszemléletét szem előtt tartva - az egyik legegyszerúbb és gyakran használt megfogalmazást preferáljuk, melyre a gyakorlati vizsgálatainkban is alapoztunk. Eszerint: a bizalom nem más, mint hajlandóság arra, hogy a többiek cselekedeteivel szemben pozitív hozzáállásunk legyen (Newman - Conrad,1999), a bizalom egy attitüd, elvárás a másik irányába, a másik viselkedésére vonatkoztatva.

Mikroszinten a bizalom az alábbi tényezőkhöz kapcsolódik: alkalmazottak elégedettsége, teljesítmény, viselkedés, csapatmunka, vezetői hatékonyság, emberierőforrás-menedzsment felfogása, sikeres tárgyalások, kommunikáció, elkötelezettség, etikus viselkedés, vállalati partnerkapcsolatok stb. Ezek alapján alapvető befolyásoló tényezőnek számít a szervezetek belső müködésében. Makroszinten a bizalom hajtóereje a szervezeti változá- 
soknak és a túlélésnek, a vállalatok együttmüködésének, stratégiai szövetségeknek és fúzióknak vagy felvásárlásoknak (Fulmer - Gelfand, 2012).

A tudásmenedzsment és bizalom fentiekben bemutatott jelentésére és az összefüggéseik nemzetközi kutatásokban megjelenő eredményeire építve, valamint ismerve a tudásmenedzsment-modell építőelemeit, fogalmaztuk meg következő hipotézisünket.

Hipotézis 2/a

A bizalom megnyilvánulása - a szervezet egésze szintjén - előfeltétel a tudásmenedzsment-modell elemeinek müködéséhez (Probst-modell elemei).

\section{Hipotézis 2/b}

A szervezeti bizalom szükséges elöfeltétel ahhoz, hogy a tudásmenedzsment kérdését stratégiai szinten kezeljék.

A szervezeten belül bizonyított, hogy a bizalomnak jelentős befolyásoló szerepe van a kooperativitásban (Zalabak - Winograd, 2000), a szervezet tagjainak egymás iránti viselkedésében (Van Dyne et al., 2000), a szervezet iránti elkötelezettségben (Aryee et al., 2002) és az alkalmazottai hüségében (Costigan et al., 1998).

A szervezeti bizalom a munkavállalók közti bizalom szintjén mutatkozik meg. A bizalmi légkör fokozza a csapatmunka, a vezetés, a célok elérésének hatékonyságát, a munkavállalók teljesítményét, az elégedettséget és az elkötelezettséget (Laschinger et al., 2001). A bizalom nemcsak a munkatársak elkötelezettségére, valamint a köztük lévő harmóniára hat pozitívan, de segíti az új ötletek kigondolását is. Korábbi kutatások azt támasztják alá, hogy a szervezeti bizalom nagy hatással van a szervezet teljesítményére is (Hoy et al., 1992; Hartzler, 2003). Mivel a legtöbb esetben nem lehetünk biztosak a másik fél hozzáállásában, a bizalom mindig hordoz magában némi kockázatot (Tarnai, 2003).

A bizalom a vezetői képesség egy jellemzője, mely a vezetők és kollégák közötti kapcsolatot is minősíti (Dittmar et al., 2007). Azok az alkalmazottak, akik bíznak a vezetőikben és szervezetükben, kreatívak, kockázatvállalók és együttmüködők (Dittmar et al., 2007). Ezt a kultúrát kialakítani, ápolni és megtartani sok odafigyelést és energiát igényel (Jármai - Csapai, 2015). Így kijelenthetjük, hogy a bizalom építése, ugyanakkor a bizalom hiánya egyaránt pénzbeli forrásokat igényel a szervezetek részéről. A fenti gondolatok segítették az alábbi hipotézis megfogalmazását.

\section{Hipotézis 3}

Amennyiben általában érvényesül a bizalmi légkör a szervezetben, a szervezeti hierarchia vertikális szintjei közötti bizalom erős.

\section{A bizalom hatásai}

Fukuyama (1996) és Kramer (1999) alapján a személyközi, illetve a gazdasági kapcsolatokban kiemelhetjük a bizalom költségcsökkentő hatását. Képes közvetlenül csök- kenteni a tranzakciós költségeket, hiszen feleslegessé teszi a kontrollt. A bizalom befolyásolja a beruházási döntéseket is. A szervezeten belüli bizalom szintje nem tekinthető statikus jelenségnek, hiszen folyamatosan változnak az emberi kapcsolatok és élethelyzetek. A személyközi kapcsolatokban a bizalom megléte csökkenti a konfliktusok számát és mértékét, ezáltal a munkahelyi stresszt. Nő az együttműködés hatékonysága, nincs szükség többszörös ellenőrzésre. Túlzott bizalom esetében azonban eltünik a gyanakvás, mely lehetővé teszi a csalást, a másik kihasználását. Szervezeti szinten megfigyelték, hogy a túlzott bizalom is káros, ugyanis növeli a konfliktusok számát, hiszen a felek teljesen nyíltan vállalják egymás előtt véleményüket, mely gyakran konfliktusforrásként jelentkezik (Zaheer et al., 1998). Ezek a hatások a munkavégzés minőségét, hatékonyságát, az információ és tudás áramlását, az emberi kapcsolatokat erőteljesen befolyásolják. Számszerüsíthető gazdasági paraméterekben kifejezhetők pl. a stressz- és konfliktuskezelés, a többszörös ellenőrzések, a folyamatos egyeztetések, az elhúzódó döntések stb. Tényként kezelt, hogy amennyiben egy csoporton belül javul a bizalom szintje, az javítja az egyén, a szervezet teljesítményét (Tarnai, 2003), de vigyázni kell a túlzásba vitt bizalom negatív következményeivel. Ez alapján megfogalmazott hipotéziseink:

\section{Hipotézis 4}

A tudásorientált szervezetek nem foglalkoznak a bizalom gazdasági hatásaival, függetlenül attól, hogy igényként jelentkezik-e a stratégiai szintü TMR-építés.

\section{Hipotézis 5}

Hiába fogalmazódik meg stratégiai szinten a TM igénye, a bizalom hiányát nem követik, és nem számolnak annak gazdasági hatásaival.

Az elmúlt években sok kutatás és azok eredményeit tárgyaló publikáció született a tudásmegosztás - mint a TM kritikus lépése - és a bizalom összefüggéseit érintően ( $\mathrm{Pa}$ liszkiewicz - Koohang, 2013; Paliszkiewicz et al., 2014; Abrams et al., 2003; Sankowska, 2013; Six, 2007). Kivétel nélkül valamennyi azt erősíti, hogy a bizalom befolyásolja a tudásmegosztás megtörténtét, annak minőségét, mélységét, így a szervezeti tudásmenedzsment (TM) rendszer építéssel és müködéssel is szoros kapcsolatba hozható. Jelen tanulmány nem az említett összefüggéseket bizonyító tanulmányok sorát kívánja szaporítani, de a kutatás eredménye kétség kívül érinti ezt az összefüggést is.

\section{A kutatási modell}

Korábbi kutatási eredmények és saját tapasztalataink alapján állítottuk fel a kutatási modellt, mely hipotéziseink összefüggéseit ábrázolja, egyúttal a gyakorlati vizsgálat, a kérdőív összeállításának alapját képezi és az eredmények kiértékelésének bázisa. A kiinduló modell a tudásorientált szervezetek és a tudásmenedzsment szervezeti stratégiában történő megjelenését és operatív szinten történő müködésének kapcsolatát teszi mérlegre a bizalom 
szempontjából. A végső cél, hogy kiderítsük, a gazdasági következmények szerepet játszanak-e a szervezeti müködés értékelése során a modellbeli összefüggések létezése, illetve hiánya esetén.

A vizsgálat elméleti modellje, mely az összefüggéseket feltételezi a 2. ábrán látható. A nyilak a kapcsolatokat, egyúttal hipotéziseinket is reprezentálják.

2. ábra

A tudásorientált szervezeti gondolkodás és a bizalom összefüggésrendszere

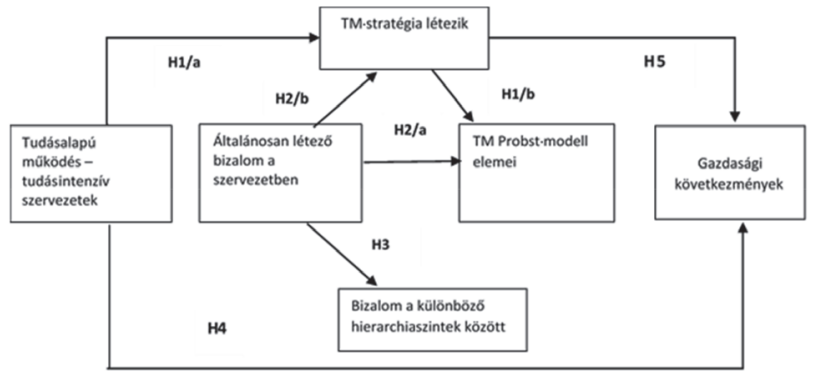

\section{A kutatás módszertana}

A szerzők 2016-ban kvantitatív felmérést végeztek. A vizsgálatok két szomszédos, de kultúrájában különböző országban, Szlovákiában és Magyarországon történtek. A kérdőívek mindkét ország esetében ugyanazokat a kérdéseket tartalmazták, kivéve természetesen a szervezetek elhelyezkedésére vonatkozóakat. A kérdőív kérdései alapvetően zárt jellegüek voltak, nominális és metrikus skálákra épültek. A próba elvégzését követően a véglegesített kérdőívek kitöltése interneten, anonim formában zajlott. A kérdőívek kitöltése bárki számára (munkahellyel rendelkező munkavállaló) elérhető volt. A kérdőív szerkezetét az 1. táblázat foglalja össze.

\section{A mintagyűjtés és értékelés}

A mintagyüjtés módszere a hólabdaeljárás volt, azaz a minta nem tekinthető reprezentatívnak. Mindkét országban közel hasonló mintaszámmal dolgoztak a kutatók, így 235 szlovák és 231 magyar szervezet töltötte ki a kérdöívet.

A kiértékelés módszerei egy- és többváltozós eljárásokból álltak, gyakorisági vizsgálatok, szórás és átlagelemzések, klaszter-, faktor- és korrelációs vizsgálatok történtek.

\section{A kérdőív szerkezete}

\begin{tabular}{|l|l|l|l|}
\hline \multicolumn{1}{|c|}{ 1. kérdéskör } & \multicolumn{1}{c|}{ 2. kérdéskör } & \multicolumn{1}{c|}{ 3. kérdéskör } & \multicolumn{1}{c|}{ 4. kérdéskör } \\
\hline \multicolumn{1}{|c|}{ Szervezeti specifikáció } & \multicolumn{1}{c|}{$\begin{array}{c}\text { Tudáskarakterizáció a } \\
\text { szervezeten belül }\end{array}$} & $\begin{array}{c}\text { Bizalom a szervezeti } \\
\text { gyakorlatban }\end{array}$ & $\begin{array}{l}\text { A bizalmi kultúra müködése és } \\
\text { gazdasági hatása. }\end{array}$ \\
\hline $\begin{array}{l}\text { Szervezet elhelyezkedése, } \\
\text { mérete, iparági müködése, } \\
\text { tulajdonviszonyai }\end{array}$ & $\begin{array}{l}\text { A tudás és annak használata, } \\
\text { tudáskezelés jellege. Tudásme- } \\
\text { nedzsmentrendszer-építés és } \\
\text { müködés jellemzöi a Probst- } \\
\text { modell logikája alapján. } \\
\text { A szervezeti tudás piaci értéke. }\end{array}$ & $\begin{array}{l}\text { A bizalom megnyilvánulása a } \\
\text { munkahelyi környezetben. } \\
\text { A bizalmi rendszer jellemzői. } \\
\text { A bizalom építésének eszközei. }\end{array}$ & $\begin{array}{l}\text { Bizalom és bizalmatlanság okai } \\
\text { a szervezetben. } \\
\text { A bizalom létezésének előnyei. } \\
\text { Bizalom és/vagy bizalmatlanság } \\
\text { következményeinek mérése. }\end{array}$ \\
\hline
\end{tabular}

\section{A vizsgált minta jellemzői}

\begin{tabular}{|c|c|c|c|c|}
\hline & \multicolumn{2}{|c|}{ Vizsgált minta } & \multicolumn{2}{|c|}{ Tudásigényes szervezetek } \\
\hline & Magyar & Szlovák & Magyar & Szlovák \\
\hline \multicolumn{5}{|c|}{ Vállalati méret } \\
\hline Mikro & 60 & 26 & 25 & 13 \\
\hline Kis & 74 & 46 & 36 & 26 \\
\hline Közepes & 53 & 53 & 22 & 29 \\
\hline Nagy & 48 & 106 & 21 & 64 \\
\hline Összesen & 231 & 235 & 104 & 132 \\
\hline \multicolumn{5}{|c|}{ Tulajdonviszonyok } \\
\hline Kizárólag hazai & 121 & 131 & 57 & 79 \\
\hline Vegyes & 53 & 26 & 16 & 12 \\
\hline Kizárólag külföldi & 61 & 74 & 31 & 41 \\
\hline Összesen & 231 & 235 & 104 & 132 \\
\hline \multicolumn{5}{|c|}{ Tevékenységi kör } \\
\hline Tudásigényes & 104 & 132 & 104 & 132 \\
\hline Munkaigényes & 106 & 86 & & \\
\hline Tőkeigényes & 21 & 17 & & \\
\hline Összesen & 231 & 235 & \multicolumn{2}{|c|}{236} \\
\hline
\end{tabular}




\section{A kutatási eredmények}

A vizsgálatok első részében a szervezeti jellemzőkön túl a tudás szerepét, jellegét és annak fontosságát elemeztük. A tudás fontosságáról szignifikánsan eltérő véleményen voltak a két ország szervezetei (Pearson-féle Khi-négyzet: 8,908 df: 2 szign.: ,012 p<0,05). A magyar cégek több mint fele $(57,6 \%)$ a tudásra épülő müködést vallotta, míg a szlovák szervezetek többsége (46,4\%) a munkaigényességet jelölte be (bár a tudásigényes müködést preferáló szervezetek a vizsgált mintában számosságukban kevéssé maradnak el).

Ezek után a szerzők kiszürték azokat a szervezeteket, ahol kimondottan a tudásorientáltság volt jellemző, azaz az előbbi kategóriák alapján összesen 236 vállalat tartozott ide. A továbbiakban ezzel a mintaszámmal számoltak a kutatók és vizsgálták a hipotézisek érvényességét. A kutatásban szereplő szervezetek legfontosabb jellemzői a 2. táblázatban láthatók.

\section{A hipotézisek vizsgálata}

\section{Hipotézis $1 / a$}

A tudásalapú szervezetek esetében a tudásmenedzsmentrendszer-építés és müködés igénye megfogalmazódik a stratégiában.

\section{Hipotézis $1 / b$}

A stratégiai szinten megfogalmazódó tudásmenedzsmentrendszer-építés igénye magával hozza a rendszerépités elemeinek megjelenését (Probst-modell elemei) az operatív müködés szintjén is.
A hipotézisek bizonyításához a kérdések a tudás szerepéről és stratégiai szintű megközelítéséről szóltak. A válaszadók saját szervezetüket minősítették egy ötfokozatú Likert-skála segítségével. Az 1-es az egyáltalán nem jellemzőt, míg az 5-ös a teljesen jellemzőt jelentette. A 3. táblázat az állításokra vonatkozó átlagokat és szórásokat mutatja.

A táblázat eredményei arra mutatnak rá, hogy a vizsgálatban szereplő tudásorientált cégek jellemzően stratégiai szinten kezelik a tudás fontosságát (H1/a) és a tudás menedzselésére számos megoldást alkalmaznak. A szervezetek jellemzően nyitottak a tudás bármilyen formájára, annak fejlesztésére és megörzésére $(\mathrm{H} 1 / \mathrm{b})$. Ez a nyitottság a cégek minden szintjén többé-kevésbé megjelenik, azaz nem feltétlenül csak a vezetők nyomására lesz népszerü a tudásmenedzsment-szemlélet, de az alulról jövő, beosztottak szintjéről induló kezdeményezések is megjelennek. Nemcsak a stratégiában, de jellemzően az operatív feladatokban is megtestesül a tudásorientáltság (H1/b). Nem véletlen tehát, hogy ez a tudatos szemlélet a kultúrába beépülve jelenik meg és lesz hatékony, amely a munkatársak figyelmét nem kerüli el a mindennapi munka során sem (H1/a, H1/b).

Kérdés volt továbbá, hogy az adott változókról különbözően vélekednek-e a szlovák és a magyar szervezetek. Miután a változók nem voltak normál eloszlásúak, így a vizsgálatok nonparametrikus eljárással történtek. A Mann-Whitney-teszt eredményei azt mutatták, hogy nem különböznek a szlovák és a magyar szervezetek abban, hogy mind a stratégiában, mind az operatív feladatokban a tudás igen nagy szerepet kap, a szervezet több szintjén is fontos elvárás $(\mathrm{H} 1 / \mathrm{a}, \mathrm{H1} / \mathrm{b})$. A tudásmenedzsmentrendszer-építés alapjaként és a stratégiában történő megjelenés

A tudás szerepe és stratégiai szintű kezelése (átlag, szórás)

3. táblázat

\begin{tabular}{|c|c|c|c|c|}
\hline \multirow{2}{*}{ Megállapítás } & \multicolumn{2}{|c|}{$\mathrm{N}$} & \multirow{2}{*}{ Mean } & \multirow{2}{*}{ Std. Deviation } \\
\hline & Valid & Missing & & \\
\hline A stratégia megfogalmazásában kiemelt szerepet kap. & 236 & 0 & 3,77 & ,998 \\
\hline A stratégiából lebontva operatív feladatokban nyilvánul meg. & 236 & 0 & 3,67 & 1,003 \\
\hline $\begin{array}{l}\text { Nem fogalmazódik meg stratégiai szinten, de mindenki tudja, hogy ez a } \\
\text { működésünk alapja. }\end{array}$ & 236 & 0 & 2,79 & 1,266 \\
\hline Több módszert használunk a tudás kezelésére, átadására vagy megőrzésére. & 236 & 0 & 3,86 & ,961 \\
\hline A vezetés erőlteti ezt a gondolkodást, de a munkatársak nem foglalkoznak vele. & 236 & 0 & 2,16 & 1,034 \\
\hline A kultúra nem támogatja, hogy komolyan vegyük a vezetés próbálkozásait. & 236 & 0 & 1,96 & 1,016 \\
\hline A munkatársak számára fontosabb, mint a vezetésnek. & 236 & 0 & 2,30 & 1,063 \\
\hline A mindennapi küzdelem a piacon elveszi a figyelmet, és ez hátérbe szorul. & 236 & 0 & 2,15 & 1,006 \\
\hline
\end{tabular}


feltételeként is megfogalmazódott a bizalom szükségessége. Ez az igény a következő hipotézis igazolását is támogatja (H2). A szlovák cégeknél jellemzőbb volt, hogy a kultúra jellemzői ellentétesek a vezetés tudásmenedzsmentrendszer-építéssel kapcsolatos próbálkozásaival, illetve a magyar szervezeteknél jobban felismerhető volt, hogy több módszert alkalmaznak a tudás menedzselésére. Látható tehát, hogy ha tudásalapú a szervezet, akkor a TM stratégiai szinten domináns, (H1/a) és a rendszerszemléletü építés igénye megjelenik, azaz a Probst-modell elemei az operatív müködésben is szerepet kapnak (H1/b).

A szerzők az adatok továbbértelmezése érdekében az adott változókat faktorokba redukálták. Egy változó kivételével (Nem fogalmazódik meg stratégiai szinten, de mindenki tudja, hogy ez a müködésünk alapja.) alkalmasak voltak a faktorképzésre. A KMO Bartlett-teszt:0,763, aprox. Khi-négyzet: 448,753 df: 21 szign.: ,000, a magyarázott varianciahányad: $61,023 \%$ volt. A Varimax-módszerrel megvalósuló rotálással 2 faktort képeztek a szerzők. A skálák reliabilitásának vizsgálata Cronbach-alfával történt, amely alapján mindegyik elfogadható érték volt (Cronbach-alfa $>0,5)$ :

1. a tudást nem stratégiai szinten kezelő szervezetek jellemzői (Cronbach alfa: ,780),

2. a tudást stratégiai szinten kezelő szervezetek jellemzői (Cronbach alfa: ,679).

Az adott faktorok segítségével klasztereket hoztak létre a kutatók. Mind a hierarchikus, mind a nem hierarchikus metódussal 3 klaszter kialakítása történt meg. A K-közép eljárással kapott klaszterközéppontokat a 4. táblázat foglalja össze.
11,134 df: 2 szign.: ,004 p<0,05), azaz, míg a magyar szervezetek többsége, 56,8\%-a stratégiai szemléletű tudásmenedzsmentre fókuszál, addig a szlovák szervezetek inkább (46,2\%-ban) elzárkóznak a kérdéstől. Összességében bizonyítást nyert, hogy a tudásalapon müködő szervezetek a tudásmenedzsment kérdését többségében stratégiai szinten kezelik és a rendszerépítés elemei az operatív szinten is megjelennek. Fentiek alapján a H1/a és H1/b hipotézist elfogadták a szerzők.

Hipotézis 2/a

A bizalom megnyilvánulása - a szervezet egésze szintjén - előfeltétel a tudásmenedzsment-modell elemeinek müködéséhez (Probst-modell elemei).

\section{Hipotézis 2/b}

A szervezeti bizalom szükséges előfeltétel ahhoz, hogy a tudásmenedzsment kérdését stratégiai szinten kezeljék.

A fenti hipotézisek bázisán az értékelés a továbbiakban a bizalom szükségességének megítélését vizsgálta. A vizsgálatban a válaszadóknak értékelniük kellett az általunk megfogalmazott definíciót, majd egy saját megfogalmazást adtak. A következő kérdésben pedig konkrétan meg kellett fogalmazniuk, hogy véleményük szerint milyen jellemzők várhatók el a szervezeten belül meglévő bizalom esetében. A következő kérdésben azt is kértük, hogy jelöljék, melyek léteznek a felsoroltakból a saját szervezetük esetében. A válaszokat értékelve az összevetés eredménye az 5. táblázatban látható.

A táblázatban az eredmények azt mutatják, hogy a bizalmi kultúra elvárt és meglévő jellemzői közel azonos

Végleges klaszterközéppontok

\begin{tabular}{|c|c|c|c|}
\hline \multirow{2}{*}{} & \multicolumn{3}{|c|}{ Cluster } \\
\cline { 2 - 4 } & 1 & 2 & 3 \\
\hline a tudást nem stratégiai szinten kezelő szervezetek & 1,05348 &,- 62089 &,- 38418 \\
\hline a tudást stratégiai szinten kezelő szervezetek &,- 03759 &, 56566 & $-1,58893$ \\
\hline
\end{tabular}

A klaszterközéppontok alapján a következő elnevezéseket kapták a klaszterek:

1. klaszter: a vállalat nem nyitott a stratégiai szemléletủ tudásmenedzsment-rendszer építésére,

2. klaszter: a vállalat nyitott a stratégiai szemléletű tudásmenedzsment-rendszer építésére,

3. klaszter: a vállalat nem foglalkozik stratégiai szemléletü tudásmenedzsment-rendszer építésével.

Az első klaszterben 82 szervezet, a másodikban 115 volt, míg az utolsóba 39 szervezet tartozott a vizsgálatok alapján (H1/a). Az elemzések során kiderült, hogy a szlovák és a magyar szervezetek szignifikánsan különböznek a klaszterbesorolás szerint (Pearson-féle Khi-négyzet:

5. táblázat

A bizalom jellemzői

\begin{tabular}{|c|c|}
\hline \multicolumn{2}{|c|}{ Bizalmi kultúra a vizsgált szervezeteknél } \\
\hline $\begin{array}{c}\text { Általánosan elvárt } \\
\text { jellemzők }\end{array}$ & Meglévő jellemzők \\
\hline Csapatmunka & Nyilt kommunikáció \\
\hline Kollegiális tisztelet & Felelösségvállalás \\
\hline Nyílt kommunikáció & Kölcsönös segítségnyújtás \\
\hline Felelősségvállalás & Munkatársi tisztelet \\
\hline Szabad véleménynyilvánítás & Csapatmunka \\
\hline
\end{tabular}


megítélést tükröznek, vagyis a vizsgált szervezetek esetében a bizalmi légkör, mint előfeltétel rendelkezésre áll (5 jellemzőből 4 egyezés). Az előző hipotézis vizsgálata során is említettük, hogy a tudásmenedzsmentrendszer-építés alapjaként és a stratégiában történő megjelenés feltételeként is megfogalmazódott a bizalom szükségességének igénye.

A tudásorientált szervezetek esetében megvizsgáltuk, hogy a bizalom hiányában megvalósulhat-e a tudásmenedzsment rendszerszintü kezelése, azaz a Probst-modell elemei megjelennek-e a mindennapi gyakorlatban (H2/a). A tudásorientált szervezetek $61 \%$-a vélte úgy, hogy a bizalom szükséges előfeltétel, 24,2\% bizonytalan választ adott, míg 14,8\% vallotta, hogy a bizalom nem szükséges. A szerzők összefüggéseket kerestek az előző hipotézis igazolása során kialakított klaszterbesorolások és a bizalom hiányában történő tudásmenedzsment megvalósulása között. Khi-négyzet próba alapján 47,672 df: 2 szign.: ,000 p $<0,05$ a két változó között volt szignifikáns kapcsolat, azaz a tudásmenedzsmentet nem stratégiai szinten kezelö szervezetek (első klaszter) 45,1\%-ban voltak bizonytalanok (igen is, és nem is választ adtak) abban, hogy a stratégiai szintű tudáskezelésnek előfeltétele a bizalom. A 2 . klaszterben található cégek, akik stratégiai szinten kezelik a tudásmenedzsmentet, ők legnagyobb részt 79,1\%-ban úgy ítélik meg, hogy a tudásmenedzsmentrendszer-építés stratégiában történő megfogalmazásának előfeltétele a bizalomra épülő kultúra (H2/b). Hasonlóan gondolkodtak a 3. klaszter vállalatai is (akik nem foglalkoznak stratégiai szinten a tudásmenedzsmentrendszer-építéssel, 61,0\%). Ezen eredmények ismeretében a H2/a és H2/b. hipotézist a szerzők elfogadják.

\section{Hipotézis 3}

Amennyiben általában érvényesül a bizalmi légkör a szervezetben, a szervezeti hierarchia vertikális szintjei közötti bizalom erős.

A hipotézis bizonyításához a szerzők által vizsgált bizalmi jegyek a következők voltak: a nyílt konfliktusok felvállalása és korrekt kezelése, a többoldalú információáramlás vertikálisan és horizontálisan, a szabad véleménynyilvánítás, a kompromisszumkészség, a nyílt kommunikáció, a szabad tudástranszfer, a kollegiális tisztelet, a megtorlások helyett megoldások keresése. E változók megléte esetében elemeztük, hogy mennyire magyarázzák a szervezet horizontális szintjén megvalósuló bizalom erősségét. Van-e kapcsolat a változók között és milyen azok hatása?

Az ANOVA vizsgálatok azt mutatták, hogy a nyílt konfliktusok felvállalása a szervezetekben nincs sziginifikáns hatással a vezetők és a beosztottak közötti bizalmi kapcsolat erősségére:

- a többoldalú információáramlás vertikálisan az alsó és a középszintü vezetők közötti bizalmat erösíti (F: 5,132 szign.: ,024 p<0,05),

- a többoldalú információáramlás horizontálisan nem gyakorol szignifikáns hatást a különböző szintek közötti bizalomra,
- a szabad véleménynyilvánítás a beosztott és középszintű vezetők (F: 3,974 szign.: ,047 p<0,05), a beosztott és felső szintü vezetők (F: 4,068 szign.: $, 044 \mathrm{p}<0,05$ ) közötti bizalomra van támogató hatással,

- a kompromisszumkészség a beosztott és a felső vezetök közötti (F: 4,571 szign.: ,033 p<0,05) bizalmat befolyásolta pozitívan,

- a nyílt kommunikáció a beosztott és az alsó szintü vezetők között (F: 4,237 szign.: ,040p<0,05), az alsó szintű vezetők és a középvezetők között (F: 4,074 szign.: ,044 $\mathrm{p}<0,05)$, valamint a felső vezetők közötti (F: 4,711 szign.: ,030 p<0,05), a bizalomra volt építő hatással,

- a szabad tudástranszfer és a kollegiális tisztelet a szervezet mind horizontális, mind vertikális szintjein is pozitív hatással van a bizalomra,

- míg a megtorlások helyett a megoldások keresése alapvetően a beosztott és az alsó szintü vezetök közötti (F: 2,346 szign.: ,018 p<0,05) bizalomra van kedvező hatással.

A vizsgálatok tükrében elmondható, hogy a szervezeti bizalmi jegyek megléte erősítő hatással van az egyes szervezeti szintek közötti bizalomra.

\section{Hipotézis 4}

A tudásorientált szervezetek nem foglalkoznak a bizalom gazdasági hatásaival, függetlenül attól, hogy igényként jelentkezik-e a stratégiai szintü TMR-építés.

\section{Hipotézis 5}

Hiába fogalmazódik meg stratégiai szinten a TM igénye, a bizalom hiányát nem követik, és nem számolnak gazdasági hatásaival.

A kutatás a továbbiakban többek között azt is vizsgálta, hogy a bizalom hiányát és annak gazdasági következményeit figyelembe veszik-e a kutatásban részt vevő, tudásorientált szervezetek (H4). A cégek 69,5\%-a alapvetően nem ügyelt erre, $22,0 \%$-uk igen is, és nem is, míg mindösszesen 8,5\%-uk, akik tudatosan odafigyelnek erre a kérdésre. E tekintetben a szlovák és a magyar szervezetek nem különböztek egymástól (Pearson-féle Khi-négyzet: 1,008, df: 2 szign.: ,604 p>0,05).

Az egyszempontú ANOVA elemzések azt igazolták, hogy azoknál a tudásorientált szervezeteknél, ahol számolnak a bizalom hiányából eredő veszteséggel, a stratégia megfogalmazásában a tudáskezelésnek fontos szerepe a jellemző (átlag 3,46). Érdekes azonban az az eredmény, hogy a stratégiai szintű tudásmenedzsment fontossága megfigyelhető (átlag 3,9) azoknál a szervezeteknél is, ahol nem fordítanak figyelmet a bizalom hiányából eredő tudásveszteség gazdasági következményeire.

A fentiekben kialakított három klaszterben található szervezetek nem különböztek abban, hogy vizsgálják-e a bizalom hiányának következményeit. A tudást stratégiai szinten kezelő szervezetek voltak legnagyobb arányban 
(12,2\%), ahol ez az odafigyelés megvolt, míg a tudást nem stratégiai szemlélettel kezelő vállalatok esetében ez az arány kevesebb, mint 5\% volt, és ezeknek a cégeknek mintegy háromnegyede nem is számolt az ebből eredő gazdasági veszteség lehetőségével.

A fentiek figyelembevételével a szerzők által megfogalmazott 4. és 5. hipotézis elfogadást nyert.

Az egész mintára visszavetítve ez azt jelenti, hogy ha a vizsgálatba bevont tudásorientált szervezetek száma 236 , ebből a tudásmenedzsmentet stratégiai szinten kezelők számossága 115, ennek a 12,2\%-a foglalkozik elvi szinten a bizalom hiányából eredő veszteség következményeivel, de nem számszerüsítik azt. Ez mindösszesen 14 szervezetet jelent. Ez az eredetileg vizsgált minta kb. $6 \%$-a. Az eredmény önmagáért beszél.

\section{Diszkusszió és összegzés}

Az eredményeink alapján több érdekes tényre szeretnénk ráirányítani a figyelmet. Az 1/a hipotézisünk igazolódott, ami azt jelenti, hogy azok a szervezetek, melyek a tudásalapú müködést preferálják, már alapvető elvárásként fogalmazzák meg a tudásmenedzsmentrendszer-építést a stratégiában. A legtöbb szervezet, amelynek a tudás kevésbé fontos, vagyis inkább tőke vagy munkaigényes a tevékenységük, egyáltalán nem foglalkozik ezzel a lehetőséggel, és a tudáskezelés, -megosztás és -megőrzés nincs azon a szinten, hogy a figyelem középpontjában a gazdálkodás meghatározó tényezőjeként kezeljék.

Ugyanakkor kimutatható volt (az 1/b hipotézis elfogadása mellett is), hogy a tudásorientált szervezetek sem egységesek abban a tekintetben, hogy stratégiai szinten kezeljék a tudásmenedzsment kérdéskörét. A vizsgált szervezetek közel fele nyilatkozott pozitívan ebben a kérdésben. A stratégiai szinttől kiindulva, a tudásmenedzsment-rendszer elemeinek működésére vonatkozó kérdéseinkre szintén vegyes válaszok érkeztek. A többségben lebontják és operatív szinten is megjelennek a Probst-modell lépései, de az egységes gondolkodás érdekében még sok teendője van mind a két ország szervezeteinek.

A gondolkodásmódbeli hiányosság megerősítését kaptuk az 2/a és 2/b hipotézis igazolása során is. A kutatási eredmények alapján azt tudtuk kimutatni, hogy a tudásorientált szervezetek nem egységesen tartják fontosnak a bizalmi kultúra jelenlétét ahhoz, hogy a TM stratégiai szinten kezelt fontosságot kapjon a szervezeti müködésben, és a rendszer elemei is kellö sikerrel müködjenek. Ez az eredmény jól mintázza azt a helyzetet, ami a magyar és szlovák kultúrában (hasonlóan a többi kelet-közép-európai országhoz) jellemző. Vagyis a gondolkodás odáig jutott csak, hogy a tudásorientált vállalatok megértették a tudásgazdálkodás szükségességét, és beépül a stratégiába az elvárás, de ennek kidolgozása, müködése a feltételek oldaláról egyáltalán nem biztosított. Az még nem jellemzö, hogy a bizalmat olyan fontos kritériumként kezeljék, mely elengedhetetlen feltétele egy tudásmegosztó kultúrának, a tudás megfelelö kezelése előfeltételeként. Ezt igazolja a 4. és 5. hipotézis eredménye is.
A 3. hipotézis vizsgálata bizonyította, hogy a tudásintenzív szervezetek esetében a bizalom mint általában jellemző szervezeti jellemző erősíti a hierarchia vertikális szintjei közötti bizalmat mind a beosztottaknál és vezetőknél, mind a különböző vezetői szinteknél. Evidenciának is lehetne tekintetni, hiszen a tudásintenzív szervezetek esetében a bizalom létezése a müködés előfeltétele és az együttmüködés záloga. A kérdés, hogy valójában igaz-e ez az elvárás a mindennapi müködés során is?

Amennyiben általában jellemző a bizalmi légkör, érvényesül a kölcsönös tisztelet, a szabad véleménynyilvánítás, a beosztottak bármilyen problémával, javaslattal fordulhatnak vezetőikhez, akik meghallgatják és válaszolnak munkatársaiknak és a tisztelet, a nyílt kommunikáció kölcsönös. A vezetök minden megfogalmazott feladat esetében bízhatnak munkatársaikban a feladat teljesítésének teljességében, határidejében, minőségében és színvonalában. Azon paraméterek jelenléte a szervezetben, melyek elvárásként fogalmazódtak meg a válaszadók részéről, mint a bizalmi kultúra jellemzői, a hipotézisünk érvényességét igazolták.

A fentiekben közzétett kutatási eredmények azt mutatják, hogy a szervezeti bizalom ma még nem elég fontos a szervezetek számára, így fel sem merül az a kérdés, hogy a túlzott bizalom vagy a bizalom hiányának következményeit úgy tartsák számon mint az eredményességet befolyásoló tényező (lásd a 4. és 5. hipotézis).

A kutatás korlátaiként kell megemlíteni, hogy nem állt rendelkezésre semmilyen támogatás (pénzügyi, fizikai és szellemi), így szükös saját erőforrással kellett megoldani azt. Ebből erednek a minta számosságának és mintavételi módszerének hiányosságai, melyeket a megfelelő forrás rendelkezésre állása esetén további elemszámmal, illetve további nemzetközi összehasonlítást lehetővé tevő országok mintáinak begyüjtésével lehet kiküszöbölni.

\section{Felhasznált irodalom}

Abrams, L. C. - Cross, R. - Lesser, E. -Levin, D. Z. (2003): Nurturing interpersonal trust in knowledge-sharing networks. The Academy of Management Executive, 17, p. 64-77.

Aryee, S. A. - Budhwar, P. - Chen, Z. (2002): Trust as a Mediator of the Relationship between Organizational Justice and Organizational Outcomes: Test of a Social Exchange Model. Journal of Organizational Behavior, 23, p. 267-285.

Ayoko, O. B. - Pekerti, A. A. (2016): The mediating and moderating effects of conflict and communication openness on workplace trust. International Journal of Conflict Management, 9, p. 297-318.

Azman, I. - Afiqah, F. N. - Madi, A. M. - Huda, M. M. N. (2013): A Study of the Correlation between Training Administration and Training Motivation. Management \& Marketing Challenges for the Knowledge Society, 8, p. $95-108$.

Bencsik A. (2013): Best practice a tudásmenedzsment-rendszer kiépítésében. London: Pearson 
Bharadwaj, N. - Matsuno, K. (2006): Investigating the Antecedents and Outcomes of Customer Firm Transaction Cost Savings in a Supply Chain Relationship. Journal of Business Research, 59, p. 62-72.

Davenport, T. H. - Prusak, L. (1998): Working Knowledge: How Organizations Manage What They Know. Cambridge MA: Harvard Business School Press

Dittmar, J, - Jennings, K. - Stahl-Wert, J. (2007): Trust and Engagement. Leadership Excellence, 24, p. 8.

Ellonen, R. - Blomqvist, K. - Puumalainen, K. (2008): The Role of Trust in Organizational Innovativeness. European Journal of Innovation Management, 11, p. 162.

Fulmer, C. A. - Gelfand, M. J. (2012): At What Level (and in Whom) We Trust - Trust Across Multiple organizational Levels. Journal of Management, 38, p. 11671230 .

Fukuyama, F. (1996): Trust: The social virtues and the creation of prosperity. New York: Penguin

Gilbert, J. - Tang, T. (1998): An Examination of Organizational Trust Antecedents. Public Personnel Management, 27, p. 321-328.

Hartzler, K. D. (2003): Study of School Collaboration and Trust. Oklahoma: Oklahoma State University

Hoy, W. K. - Tarter, C. J. - Witkoskie, L. (1992): Faculty Trust in Colleagues: Linking the Principal with School Effectiveness. Journal of Research and Development in Education, 26, p. 38-45.

Jármai, E. M. - Csapai, E. (2015): Emotional factors affecting the activity of knowledge managers in education. In: Csata A. et al. (szerk.): 12th Annual International Conference on Economics and Business: Value changes in a transforming economy: Challenges in the Carpathian Basin. Konferencia helye, ideje: Csíkszereda, Románia, 2015.06.05-2015.06.06. Kolozsvár: Editura Risoprint, 2015. p. 272-287.

Kelman, H. C. (2005): Building Trust among Enemies: The Central Challenge for International Conflict Resolution. International Journal of Intercultural Relations, 29, p. 639-650.

Kramer, R. M. (1999): Trust and distrust in organizations: Emerging perspectives, enduring questions. Annual Review of Psychology, 50, p. 569-598.

Kuburic, Z. - Kuburic, A. (2010): Degree of Trust in the Western Balkans and Bulgaria. Balkan Journal of Philosophy, 2, 1, p. 79-94.

Lane, C. (1998): Introduction: Theories and Issues in the Study of Trust. In: Lan, C. - Bachman, R. (eds.) (1998): Trust within and between Organizations, Conceptual Issues and Empirical Applications. Oxford: Oxford University Press, p. 1-30.

Laschinger, H. K. P. - Shamian, J. - Thompson, D. (2001): Impact of Magnet Hospital Characteristics on Nurses' Perceptions of Trust, Burnout, Quality of Care and Work Satisfactions. Nurse Economics, 19, p. 209-219.

Lopez-Fresno, P. - Savolainen, T. (2014): Working Meetings - a Tool for Building or Destroying Trust in Knowledge Creation and Sharing. The Electronic Journal of Knowledge Management, 12, 2, p. 137-143.
McAllister, D. J. (1995): Affect- and Cognition-Based Trust as Foundations for Interpersonal Cooperation in Organizations. Academy of Management Journal, 38, p. 24-59.

Newman, B. - Conrad, K.W. (1999): A framework for characterizing knowledge management methods, practices, and technologies. Characterizing Knowledge Management Tools, Toronto: Documation '99

Nooteboom, B. (2002): Trust: Forms, Foundations, Functions, Failures and Figures. Cheltenham: Edgar Elgar

Olekalns, M. - Smith, P. L. (2005): Moments in Time: Metacognition, Trust, and Outcomes in Dyadic Negotiations. Personality and Social Psychology Bulletin, 31, p. $1696-1707$.

Paliszkiewicz, J. - Koohang, A. (2013): Organizational trust as a foundation for knowledge sharing and its influence on organizational performance. The Online Journal of Applied Knowledge Management, 1, p. 116127.

Paliszkiewicz, J. - Koohang, A. - Nord, J. H. (2014): Management trust, organizational trust, and organizational performance: Empirical validation of an instrument. Online Journal of Applied Knowledge Management, 2, p. 28-39.

Paliszkiewicz, J. - Koohang, A. - Gołuchowski, J. - Nord, J. H. (2014): Management Trust, Organizational Trust, and Organizational Performance: Advancing and Measuring a Theoretical Model. Management and Production Engineering Review, 5, p. 32-41.

Probst, G. J. B. (1998): Practical Knowledge Management: A Model that Works. in: Arthur D. Little: Prism/ Second Quarter, p. 17-29. o.

Prusak, L. (1999): What's up with knowledge management? A personal view. in: Cortada, J. W. - Woods, J. A. (eds.): The knowledge management yearbook 19992000, 3-7. Boston MA: Butterworth Heinemann

Rahman, M. S. - Osman-Gani, A. M. - Momen, M. A. - Islam, N. (2015): Testing knowledge sharing effectiveness: trust, motivation, leadership style, workplace spirituality and social network embedded model. Management \& Marketing. Challenges for the Knowledge Society, 10, p. 284-303.

Rousseau, D. M. - Sitkin, S. B. - Burt, R. S. - Camerer, C. (1998): Not so Different After All: A Cross-Discipline View of Trust. Academy of Management Review, 23 , p. $393-404$.

Sankowska, A. (2013): Relationships Between Organizational Trust, Knowledge Transfer, Knowledge Creation and Firm's Innovativeness. Learning Organization, 20, p. 85-100.

Six, F. (2007): Building interpersonal trust within organizations: a relational signaling perspective. Journal of Management of Governance, 11, p. 285-309.

Tan, H. H. - Lim, A. K. H. (2009): Trust in Coworkers and Trust in Organizations. The Journal of Psychology, 143 , p. 45-66.

Tarnai M. (2003). A bizalom szerepe a gazdasági kapcsolatokban. In: Hunyady Gy. - Székely, M. (eds.) (2003): Gazdaságpszichológia. Budapest: Osiris, p. 676-715. 
Van Dyne, L. - Vandewalle, D. - Kostova, T. - Latham, M. E. - Cummings, L. L. (2000): Collectivism, Propensity to Trust and Self-Esteem as Predictors of Organizational Citizenship in a Non-Work Setting. Journal of Organizational Behavior, 21, p. 3-23.

Wech, B. (2002): Trust Context: Effect on organizational citizenship behavior, supervisory fairness and job satisfaction beyond the influence of leader-member exchange. Business and Society, 41, p. 353-360.
Zaheer, A. - McEvily, B. - Perrone, V. (1998): Does Trust matter? Exploring the effects of interorganizational and interpersonal trust on performance. Organization Science, 9, p. 141-159.

Zalabak, P. S. - Winograd, E. K.G. (2000): Organizational Trust: What It Means, Why It Matters. Organization Developmental Journal, 18, p. 35-49.

Zand, D. E. (1997): The Leadership Triad, Knowledge, Trust and Power. New York: Oxford University Press 